\title{
BENZEDEIRAS POLONESAS: MANTENDO A LÍNGUA POLONESA E AS PRÁTICAS DE CURAS TRADICIONAIS VIVAS.
}

\author{
Polish Folk Healer: Keeping the Polish Language and Traditional Healing \\ Practices Alive.
}

\author{
William Franco GONÇALVES \\ Universidade Estadual do Centro-Oeste \\ w.f.g@hotmail.com \\ https://orcid.org/0000-0003-4760-2247
}

\begin{abstract}
RESUMO: Esta pesquisa faz parte de uma pesquisa maior feita em minha dissertação de mestrado na UNICENTRO e apresentada no ano de 2019, com o titulo "Rezas, benzeções e práticas de cura para humanos e animais não humanos (1931-2018)". Este é um estudo sobre benzedeiras moradoras do município de Irati, Rio Azul e Mallet, localizada na Região Centro-Sul do Estado do Paraná. Esta investigação se deu através da História Oral e tem como objetivo analisar e compreender alguns aspectos das práticas de benzeção destas pessoas, entre elas a prática de benzeções de animais. Entre esses praticantes estão incluídos ascendentes de poloneses, moradoras da cidade de Rio Azul e Mallet, compreendendo assim como as praticas de benzeções não estão restrito apenas ao espaço afro-ibero-indígena das benzeções, mas também a cultura Eslava. Com a ajuda da benzedeira Palmira Lewandowski que ainda preserva em sua família a língua de seus antepassados, obtivemos também alguns nomes de doenças em polonês que estas benzedeiras costumam curar. Essas pessoas estão habituadas a benzer tanto usando rezas em português quanto em polonês.
\end{abstract}

PALAVRAS-CHAVES: Benzedeiras; Ascendentes de poloneses; Curas; História Oral.

ABSTRACT: This research is part of a bigger study done in my Master's
Thesis at UNICENTRO and presented in the year of 2019 under the
title "Rezas, benzeções e práticas de cura para humanos e animais não
humanos (1931-2018)". This is a study about the folk healers that live
in the cities of Irati, Rio Azul and Mallet, located on the Center-South
Region of the State of Paraná. This research happened through the Oral
History and has as its objective to analyze and understand some aspects
of the healing practice of these people, among them, the healing practice
of animals. Among these practitioners are included polish ascendents,
dwellers of the city of Rio Azul and Mallet, knowing this, we could 
gain a better understanding about how the practice of healing is not restricted to afro-ibero-indigenous spaces only, but also to the Slavic culture. With the help of the folk healer Palmira Lewandowski, who still preserves her ancestors language in her family, hence, we also got the polish names of some diseases that these folk healers use to cure. These people are used to heal praying in both languages, portuguese and polish. KEYWORDS: Folk healers; Polish ascendents; Healing; Oral History.

\section{TRABALHO E PACIENTE FIXO}

Esta opção por benzedeiras que fizessem parte desse grupo específico foi possível devido ao fato de que durante o ano de 2018 tive a oportunidade de participar de um intercâmbio internacional, graças a uma bolsa de estudos ofertada pelo Centro de Línguas, o Núcleo de Estudos Eslavos da UNICENTRO e o Consulado Geral da República da Polônia no Brasil. Como aluno do curso de polonês ministrado pela professora Sônia Niewiadomski ${ }^{1}$ desde o ano de 2015, recebi uma bolsa para participar do Curso de Verão de Língua, Literatura e Cultura polonesa na Universidade da Silésia, na cidade de Cieszyn - Polônia. Então, durante quarenta e cinco dias eu tive a oportunidade de conhecer e aprender um pouco e praticar o que eu já havia aprendido no curso de que faço parte. Reguina Kovalczyk Drewnowski, aluna do curso de polonês ofertado na cidade de MalletPR, também estava nessa atividade de intercâmbio e nos auxiliou nesta parte da pesquisa.

Durante esse tempo que estive lá conversei, fui interrogado a respeito da minha pesquisa em conversa com duas professoras da universidade de Varsóvia e que falam português. Elas informaram que, na Polônia, também havia algumas mulheres que atuavam como benzedeiras, que curavam através de rezas e simpatias, mas que seu número era reduzido e que viviam em regiões afastadas, em vilarejos do interior do país.

Reguina acompanhou as conversas e me disse que conhecia algumas benzedeiras com ascendência polonesa e que moravam no interior Mallet-PR. Este dado me chamou a atenção porque no imaginário popular a benzedeira ou benzedor e mesmo na imensa maioria dos estudos sobre benzeção, costumam ser retratados como pessoas com traços culturais caboclos, indígenas, afro ou ibéricos, mas dificilmente uma pessoa associada às culturas eslavas seria considerada como praticante de benzimentos. Devido a isso, começamos a entrar em contato com as pessoas que eu conhecia e as que a Reguina e

\footnotetext{
${ }^{1}$ Graduada em Letras Polonês pela Universidade Federal do Paraná em 2013, mestrado em Relações Internacionais com conclusão em 2015 na Uniwersytet Warszawski e mestre em Letras pela Universidade Estadual do Centro-Oeste em 2019.
} 
outros informantes indicaram a mim. A ideia era saber se elas também benziam animais ou se isso estaria restrito ao espaço afro-ibero-indígena das benzeções. Também, pretendia investigar se entre os ascendentes de eslavos alguns nomes de doenças são nomenclaturas de animais, como é sapinho, nas partes do Brasil sem influência eslava.

Para a realização desta pesquisa foi escolhido o método da História Oral. O método da História Oral se apresentou como o melhor e mais completo método para se pesquisar as benzedeiras e os benzedores de Irati. Pois assim como cita Ferreira e Amado no livro Usos e abusos da história oral,

possibilita a história oral esclarecer trajetórias individuais, eventos ou processos que às vezes não tem como ser entendidos ou elucidados de outra forma: são depoimentos de analfabetos, rebeldes, mulheres, crianças, miseráveis, prisioneiros, loucos... São histórias de movimentos sociais menosprezados; essa característica permitiu inclusive que uma vertente da história oral se tenha constituído ligada à histórias dos excluídos (2006, p. 14).

O documento da História Oral possui algo singular, é o resultado do diálogo entre entrevistador e entrevistado. Para esse dialogo durante as entrevistas utilizamos de uma mistura entre o roteiro aberto e fechado, onde as entrevistadas respondiam as nossas perguntas, mas também ficavam livres para nos contar mais sobre o assunto. Escolhemos essa mistura para ter um acesso melhor às falas dessas benzedeiras.

De forma geral, e como vimos até agora, os agentes da benzeção não estabelecem distinções muito clara entre animal humano e animal não humano uma vez que o benzimento pode ser aplicado a um e a outro, no mesmo espaço, inclusive. No mundo racionalizado, os primeiros são tratados em lugares específicos como os hospitais e clínicas especializadas enquanto que os segundos são tratados nos espaços Pets e em clínicas veterinárias. Seria muito raro, talvez impossível, encontrar algum lugar em que os medicamentos para humanos e animais fossem vendidos na mesma prateleira.

Sonia Sidoski é moradora da cidade de Irati, bairro Rio Bonito, nascida em 1947. Disse ter iniciado a aprendizagem do ofício desde muito pequena. Nem mesmo consegue lembrar-se da época precisa. "Olha eu aprendi desde criança, mas assim, oh. Eu trabalhava na roça, eu fui aprendendo com meu, com o tio do meu pai. Ele estava ensinando meu pai e fui aprendendo com ele. Então desde criança eu ajudava, eu ajudava meu pai” (2019).

Diz que, por muitos anos, morou no interior da cidade de Irati. Trabalhava na lavoura e ao mesmo tempo, atendia as pessoas que a procuravam. Mudou-se para a cidade onde continua atendendo seus clientes e, portanto, viveu duas experiências neste campo 
da cura: a de ser benzedeira no campo e também, na cidade. Disse que trabalha "[...] fixo, uns quinze a vinte anos. Toda a vida eu atendi. Eu estava na roça, eles me chamavam. Eu estava lá assim carpindo e minha filha vinha: mãe tem gente; e eu vinha" (Sonia Sidoski, 2019). Quando voltava do trabalho na lavoura, atendia às pessoas que a procuravam em sua casa.

Sonia vivia no interior, mas precisou se mudar para a cidade em 2014. Agora mora com o marido e uma de suas filhas. Disse que o número de clientes continuou o mesmo depois da mudança.

Mesma coisa. Mesma coisa. Na serra não tinha ninguém (outras benzedeiras) e a sogra começou a falar e a turma foi um contando para outro. E eu vim para a cidade e eu achei que ia ficar mais tranquila, mas mais ainda. Por aí um diz que está na cidade, está mais perto, que lá na BR é difícil. É trecho pesado (Sonia Sidoski, 2019).

Os atendimentos feitos por ela se dão em um dos maiores bairros da cidade de Irati, o Rio Bonito. A localidade onde morava anteriormente fica na saída da cidade, Serra dos Nogueiras, é também um bairro pertencente ao município de Irati. Disse que lá, trabalhava com o marido como chacareiros até que seu patrão precisou vender a propriedade e eles foram obrigados a sair.

Sônia falou a respeito de sua atuação como benzedeira na chácara. Disse que sentia muitas saudades e que, lá, tinha acesso às plantas que utilizava para fazer remédios. Contou, também, que na chácara havia aprendido a benzer e a curar animais.

Sobre as plantas disse que lá

[...] tinha remédio para ensinar. Lá era mais fácil. Eu dizia oh! Você está com uma ferida braba; está com um urticário (sic.); está com frebite (sic.); está com ulcera varicosa'. Então a gente dizia: olha, esse remédio você vai achar. Aqui não tem, não tem como mostrar. Então lá a gente não ficava tão perdido. [...] Tudo que é mato é remédio, mas sabendo fazer. Lá era mais fácil, como por exemplo curar anemia. Anemia não é fácil de curar. Você sabe que a anemia prejudica a pessoa que deus o livre. Então anemia, que você tome a tiririca. Ontem estava aqui uma mulher que estava com a menininha com uma anemia braba. Então a gente cura a anemia na minguante, tem as fases da lua. Daí, ela disse eu não conheço. Aí eu fui ali e não sei como tinha um pé de tiririca. E eu disse olha, é esse aqui. Você vai ter que achar esse pé de tiririca. E é uma praga para o colono, porque não tem veneno que mate. Ele dá tipo uma cebolinha, mas ele dá um remédio. Para mim tudo que é mato é remédio, mas sabendo fazer. Então lá era mais fácil ensinar. Aqui eu ensino sim bastante, mas lá era mais fácil (Sonia Sidoski, 2019). 
Maciel e Neto (2006, p. 64) escreveu que

No Brasil é comum a troca de receitas que envolvem plantas na cura de enfermidades. Geralmente tais fórmulas foram elaboradas por pessoas mais idosas que experimentaram, testaram e aprovaram estas receitas [...] São as avós, tias, comadres, benzedeiras e rezadores, xamãs, que mantêm esse milenar hábito de uso das plantas na medicina não oficial da cultura brasileira, e em muitas localidades é o único auxílio 'médico' existente, especialmente em áreas onde centros de atendimento médico são inexistentes ou muito distantes

Devido à mudança de ambiente, Sônia precisou adaptar seus conhecimentos, mas quando é realmente necessário, disse, pede ajuda ao marido para encontrar as plantas adequadas. Além disso, orienta seus clientes a procurá-las nas lojas que vendem produtos naturais. 'O bálsamo que eu dizia 'passe balsamo para desinchar a perna' hoje já tem a pomada bálsamo" (2019).

\section{“ARRUMANDO" CRIAÇÃO}

Sobre o benzimento de animais Sonia refere-se ao tempo passado, de sentimentos muito agradáveis e de boas recordações. Disse que tudo começou com um boi que nasceu lá na chácara em que trabalhava com o marido.

Aconteceu por causa desse boi. Porque o patrão foi lá. Nós nos mudamos em junho e em setembro, nasceu um boizinho, lá. Um boi, aquele boi de cupim. Não sei como se diz; aqueles bois que tem um cupimzão. Ele nasceu com esse osso (a paleta) daqui para trás. Ele nasceu virado. Aí, quando ele nasceu, daí o Carlos (veterinário) disse: oh seu Ambrósio (patrão) não tem o que fazer. Tem que matar. Mandou-nos matar. E eu disse :João (marido) eu não vou matar esse boi, eu vou arrumar. Eu peguei, fui lá e pus pra cá (para o lado correto) e daí eu enfaixei e aí nos erguia para dar de mamar. Aí nós íamos dar de mamar para ele e nós erguia em dois. E eu disse; oh seu Ambrósio eu preciso de uma Calminex. Ele disse, porque? Eu disse: eu vou curar. Ele disse: não vão matar? Eu disse: não. E ele disse: uma semana eu não venho aqui, que eu não quero ver o sofrimento desse bichinho. Eu disse: não, só me mande uma pomada. [...] Não levou um mês e ele começou a andar (Sonia Sidoski, 2019).

Sonia nos contou a história emocionada. Era o primeiro animal que ela havia curado e mesmo tendo o veterinário dito não haver cura ela precisava tentar. "Assim como eu ajudo as pessoas, eu precisava ajudar ele" (2019). Com os conhecimentos de 
benzedeira, também sabia arrumar um osso quebrado, colocar um musculo no lugar. Sonia se apegou ao animal.

O boi era muito manso, era muito manso, muito. Quando o patrão vendeu ele eu cheguei a chorar. Ele vendeu para matar; para carne. Que era um boi... um baita de um boizão. Um boi lindo, lindo, lindo. Até tem foto do meu filho montado. Eu não sei onde está, senão eu tinha achado. Aquilo era muito mansinho (Sonia Sidoski, 2019).

O caso do boi de cupim marcou a história de Sonia como benzedeira de animais. O sucesso na cura fez aparecer e aumentar sua fama como curandeira de gado. Logo as pessoas começaram a trazer suas criações e seus pets para serem benzidos e curados.

Olha isso aconteceu, tem uns quinze anos ou talvez mais. Uma mulher chegou lá e disse assim: a menina derrubou o cachorrinho da janela. Eu não sei se não quebrou a patinha. Eu digo: vamos arrumar, né? Eu arrumei. Peguei dois pauzinhos assim, amarrei com duas faixinhas assim e pus na patinha e fiz uma faixa e digo: deixe ele ficar uma semana, com esse curativo. Digo, ele não vai mexer a patinha. E daí, depois eu digo: depois daí, traga que a gente tira e vamos ver. Daí ele ficou bem da perna. Então, aí você veja, daquela mulher ela foi falando para os outros, assim como as outras pessoas, que eu arrumo criação. Então daí quantos, quantos que eu já arrumei de criação (Sonia Sidoski, 2019).

Com base nas datas fornecidas na entrevista, podemos dizer que a benzedeira atuou por cerca de dez anos como arrumadeira de criação na chácara de Ambrósio. Sendo assim, esse tipo de atividade começou em torno do ano de 2004. Mas depois que passou a morar no bairro do Rio Bonito, precisou fazer umas adaptações porque dificulta o transporte dos animais de grande porte até o local de atendimento. Sonia encontrou uma saída eficiente para o problema: passou a benzer o gado por meio do telefone e até mesmo através do aplicativo WhatsApp.

Às vezes eles me ligam e dizem: oh! meu cavalo está com uma bicheira. E eu digo: então pegue lá três ramos... Eu explico, o ramo, um copo de água e vá lá na bicheira. Eu daqui, pelo celular, vou contando para ele lá. Às vezes eu vou na casa do outro, né? Mas eu não gosto de ir na casa dos outros. Prefiro eu ensinar e eles façam na casa. Ensinar não muda. Animal também precisa. Sim! Precisa de muita proteção para os animais (Sonia Sidoski, 2019).

Podemos perceber que mesmo para continuar com suas práticas de benzeções 
ela precisou adaptar e reformular a forma como exercia seu ofício. A tecnologia de comunicação se torna um espaço de estreitamento das relações e de diluição das fronteiras entre os animais humanos e os não humanos, porque, como gente, os animais são benzidos à distância. O WhatsApp foi lançado em 2009 e logo se popularizou. Passou a fazer parte do cotidiano de inúmeras pessoas superando a casa dos cem milhões de usuários no Brasil. Para a benzedeira Sonia não foi diferente. Com o auxílio do neto, aprendeu a usar o aparelho de celular e assim passou a atender pessoas que moram em outros bairros, outras cidades e até mesmo em outros estados.

Às vezes, de noite eu estou ali, deitada e olho o celular e está cheio de mensagem. E aí eu vou respondendo. Respondendo e mandando o que fazer. Oh! o que eu aprendi: meu neto me ensinou a falar em áudio. Aí, em áudio, para mim é mais fácil. Ele disse: a vó aperta aqui, fala e aí a vó manda. Que daí é mais fácil. Daí, falam lá: meu cavalo ficou doente. Eu digo: vamos fazer um remédio; e mando dar. E aí eu pergunto: o que está acontecendo? Eles dizem: acho que prendeu a bexiga. É um cavalo ou uma égua? É uma égua. Então pegue o chinelo do teu marido e passe em cruz na barriga dela. Oh! Isso é uma simpatia... e dê chá de salsa. Então veja... por telefone. A turma agora mais está procurando por telefone, porque eles estão longe, né? É longe não tem como; então a gente faz (Sonia Sidoski, 2019).

O celular pode ser considerado como um novo utensílio no ritual de benzimento. O uso de utensílios e objetos além de imagens de santos é comum em algumas práticas de benzeções, como por exemplo, o pano para a prática de "costura", a cera de abelha, no rito de derramar cera. Podemos dizer, portanto, que o aparelho celular utilizado para os rituais de cura, naquele momento, adquire outro significado: mais do que um mecanismo de comunicação. Durante o tempo em que a benzeção acontece, se torna o elo ou a ponte entre a agente de cura e a pessoa ou animal a ser curado. Como se o celular naquele momento fosse uma extensão do corpo do bicho ou da gente, assim como acontece com a utilização de fotografias ou quando alguém traz o nome de um parente ou amigo, ou de uma criação para ser benzido. "Naquele momento durante a benzeção, aquela fotografia e aquela folha de papel onde está o nome do animal humano ou do não humano, se tornam uma extensão do corpo doente" (VAZ, 2006, p. 100).

Além de benzer para curar animais, Sonia também conhece simpatias e rezas para afastar criaturas indesejadas, prejudiciais ou incômodas. Esses benzimentos do âmbito da câmara dos não humanos, segundo ela, são dos mais procurados pelas pessoas que vão a ela. Costuma-se solicitar tais práticas quando surgem, em suas casas, muitos insetos 
ou animais vistos como repugnantes e quando falham os repelentes e outros defensivos. Sonia explicou o seguinte:

[...] eu atropelo formiga, espanto lagarta, lesma, rato e aranha. Tudo que é inseto que te prejudica. Esse é tudo o que te prejudica. A gente amaldiçoa, mas não manda para ninguém. Não precisa ter medo, porque tem gente que manda. Mas eu não. Eu mando para um lugar que não tenha, pão, vinho e nem água (Sonia Sidoski, 2019).

Conforme nos esclareceu, direciona esses animais para locais sem pão, sem vinho e sem água. Por que o pão e o vinho são alimentos muito importantes, disse. Foram deixados por Jesus; e água, é para um local que tenha pouca água: "todo mundo toma água, nós e os animais, mas em um lugar com pouca água, esses animais vão se acabando" (2019).

Para Sonia espantar pulgas, ratos, formigas e para todo tipo de animal implica convencê-los por meio de uma conversa. Disse que "as pessoas não sabem conversar com os animais, a gente tem que conversar com eles. Você pode conversar com animais, isso já falaram para você? Sabia que você pode conversar com animais?" (2019). Então, isso é algo que todos podem fazer sozinhos sem recorrer a nenhuma força superior; mas que as pessoas não sabem falar com os bichos, não têm paciência com os animais.

[...] você chega lá e fala com eles. Pede para ir embora. Fala que aquele não é lugar deles, que eles precisam ir. Mas, você tem que saber falar com eles, não pode chegar xingando. Não pode gritar e brigar com eles. Porque eles sentem e eles não vão ir embora (Sonia Sidoski, 2019).

A partir da leitura dos escritos de Thomas (2010, p.135) ficou claro que a conversação com animais não humanos, bem como a atitude de percebê-los como seres capazes de compreender a linguagem usada pelos animais humanos não é novidade. No caso dos domésticos, na Inglaterra do início da modernidade

Também era comum que se falasse com eles, pois seus donos, ao contrário dos intelectuais cartesianos, nunca os consideravam incapazes de entender. "Olá, olá rapaz! Vem, pássaro, vem", diz Hamlet, e os dicionários de dialetos oferecem-nos ampla gama de tais formas de tratamento.

Sonia nos relatou que, além de convencer os animais considerados como pragas a deixarem os humanos em paz, também sabe essa linguagem dos animais domésticos, 
como vimos apontada por Thomas. Disse que ensina técnicas de falar com o gado para as pessoas que a procuram e também, instrui como treinar esses animais, principalmente quando as pessoas reclamam que seus cavalos ou vacas não querem ir para o pasto ou não querem fazer seu trabalho. Explicou que pergunta a quem a procura:

[...] você treina o cavalo? Diga para o cavalo: eu vou dar milho para você comer. Coma para você ganhar o pão de cada dia para o seu sustento. Se você não ir trabalhar você não vai ter comida. Igual para um jovem. Jovem vai trabalhar para ganhar o pão de cada dia. A mesma coisa, o cavalo. O cavalo é ruim. Se você surrar o cavalo ele te dá coice. Se você agradar ele, ele te dá carinho. Ele esfrega o fuço dele, ele dá muita coisa boa. Como o cachorro. O cachorro se você é inteligente, você bate no chão e não nele e fala para ele o que tem que fazer (Sonia Sidoski, 2019).

Podemos dizer que se trata de um saber muito antigo no âmbito do trato com os animais de trabalho, passado de uma geração à outra, de uma maneira geral. Thomas nos mostra que, na Inglaterra, para animais de labuta como os cavalos, as técnicas de conversa que existiam nos dicionários de dialetos eram mais extensas do que para os outros animais domésticos.

"Cavalos e mulas", afirmava um autor seiscentista, "entendem a
linguagem dos carroceiros, que com seus termos de oficio como
"Gee' e "Ree' e outros semelhantes fará com que avancem ou parem,
virem à esquerda ou direita, segundo sua vontade [...] Os cavaleiros
aristocráticos empregavam vocabulário mais altivo. Os mestres de
equitação recomendavam "Ha, Villain" [ah, Vilão], "Diablo!", e
"ameaças do gênero"; ou se o cavalo devia ser incentivado, "olá, assim
rapaz, aí rapaz, aí!". Os domadores profissionais adquiriram a reputação
de serem capazes de se comunicar por assovios ou um cochichar
misterioso no ouvido do animal (2010, p.135-136).

Sonia disse que certas criaturas que infestam animais causando-lhes doenças precisam de uma abordagem mais agressiva para cessar os males que fazem. Nestes casos é preciso que se faça um rito usando fórmulas de maldição. Sonia explicou que "bicheira a gente amaldiçoa. Bicheira, berne, carrapato a gente amaldiçoa”. Disse também que quando uma bicheira se torna muito grande e ela não consegue cortar o mal, pede a São Jorge para ajudá-la. "E aí bicheira a gente amaldiçoa; amaldiçoar... e se ele não vai, aí a gente pede para São Jorge que amanse a bicheira, que ela fique calma" (Sonia Sidoski, 2019). 
Sonia explicou que benzia porque tais doenças são causadas por parasitas.

Eles são animais, né? Eles tão fazendo o que sabem fazer, mas às vezes eles são muitos, eles começam a fazer mal para o cavalo, mal para a vaca e aí a gente tem que tirar. Aí uma reza às vezes não funciona, às vezes a simpatia funciona, às vezes São Jorge ajuda, mas às vezes é preciso amaldiçoar. Aí, é como eu te falei. Aí a gente amaldiçoa, corta eles e eles acabam (Sonia Sidoski, 2018).

Estas práticas, no entanto, se aplicam à parasitas externos. Quando se trata de infestação interina, "A gente reza para Deus, né? Para ele curar aquela criação; você diz o nome da criação e faz a oração e pede para a Santíssima Trindade para curar aquela criação que está precisando" (Telina Qulis, 2019). Quando pedimos um exemplo de cura que ela tinha alcançado para algum animal, nos contou sobre uma de suas vacas que estava doente há alguns meses.

[...] eu faço assim para terneiro quando tem bicha². Até a mãe dessa vaquinha ali (apontou para o animal que pastava próximo da casa) estava quase morta e demos remédio do veterinário e tudo; e nada adiantou. Aí eu disse para a minha neta: vamos fazer um remédio de casa. Eu peguei e pus esse soro de leite azedo, sabe? na água e alho e "taquemo"3 nas ventas dela, sabe? Meia garrafa mais ou menos. Aí peguei dois ovos e também, "taquemo" em cima. Aí, pegamos leite fresco e "taquemo" por cima de tudo. Quando foi no outro dia, a terneira ${ }^{4}$ lavou a estrebaria de bicha, sabe? [...] Aí, hoje está bem. Está até hoje aí se criando (Telina Qulis, 2019).

Benzedeiras (ores) ascendentes de poloneses, como explicado no início do capítulo, era um dos nossos objetos de pesquisa. Na cidade de Irati encontramos a benzedeira Sonia Sidoski que tem esta descendência; as outras pessoas entrevistadas moram em Mallet e Rio Azul.

Essa região toda é assim povoada porque, durante o século XIX e início do $\mathrm{XX}$, o Brasil recebeu centenas de milhares de imigrantes vindos diferentes lugares do mundo, sobretudo da Europa. Muitos deles vinham com o sonho de uma vida melhor, de enriquecer e de, talvez, voltarem para suas regiões com uma situação financeira melhor,

\footnotetext{
${ }^{2}$ Lombrigas.

${ }^{3}$ Administramos.

${ }^{4}$ Bezerra.
} 
segundo Teleginski (2016 p. 73).

Quando se considera a imigração polonesa constata-se o sonho daqueles imigrantes em se tornarem proprietários de um pedaço de terra ou conseguirem trabalho para colocar comida na mesa. Ao deixarem suas aldeias, muitos dos que emigravam eram vistos por seus alguns de seus conterrâneos, que se engajavam em movimentos sociais contra a opressão vivida, como traidores, por "abandonarem" a luta pela liberdade da Polônia que se encontrava sob o domínio estrangeiro.

Durante o período que se estende entre o século XVIII e o início do XX a Polônia estava dividida entre três grandes potências, a Prússia, a Áustria e a Rússia. E sob esse regime, os poloneses sofreram com "desnacionalização". Nesse contexto, era proibido que essas pessoas usassem sua língua materna ou realizassem manifestações artísticas e culturais ligadas à nação. (TELEGINSKI, 2016, p. 74). Muitos desses poloneses viram no Brasil como um lugar onde estariam livres, mas devido à tripartição do território polonês, muitos desses imigrantes não foram reconhecidos como poloneses, e sim "classificados nas estatísticas oficiais com diferentes denominações, ora como poloneses ou polacos, ora como austríacos, galicianos, silesianos, russos e até mesmo alemães” (TELEGINSKI, 2016, p. 75).

Niewiadomski (2018, p. 3) escreveu que

A região sudeste do Paraná é caracterizada pela emigração eslava, polonesa e ucraniana, nessas comunidades a cultura eslava continua viva e os descendentes preservam as tradições de seus antepassados, seja na culinária, nos ritos religiosos, no artesanato típico, nas crenças e, principalmente, nos sistemas linguísticos trazidos pelos seus ancestrais.

Ora, se eles (ou pelo menos alguns deles) mantêm os rituais, as crenças e a língua e se algumas dessas pessoas atuam com benzeções, então, podemos ver a especificidade dessas práticas no ambiente da eslavicidade. Encontramos algumas pessoas de origem eslava que também são benzedeiras, mas nem todas preservaram a língua de seus ancestrais.

\section{SAPOS E COGUMELOS.}

Lúcia Kruk administra um espaço de tipo "pesque e pague”, com sua família, na cidade de Rio Azul. Nos contou como começou a benzer. Disse que herdou o conhecimento de sua mãe e já fazem trinta e quatro anos que trabalha como benzedeira, uma vez que Revista X, v. 15, n. 6, p. 378-398, 2020. 
começou o ofício por volta de 1985. Explicou que, no início, não tinha muita fé que aquelas coisas dariam certo, até que um dia, o filho de uma vizinha precisou da sua ajuda.

[...] quando ele chegou aqui... Tipo as bichas atacaram e aí ele começou assim, espumando e vomitando. Aí, ela pediu para eu fazer; e aí eu fiz, né? Peguei a cera, porque para as bichas é a cera que corta. Aí, eu benzi das bichas e não deu quinze minutos e aquele menino estava normal, sabe? (Lucia Kruk, 2019).

Lúcia relatou que mesmo herdando os conhecimentos de sua mãe - uma ascendente de poloneses - a maior parte das rezas para curar doenças aprendeu com a sogra, também possuía antepassados que eram imigrantes vindos da Polônia. Sobre a mãe do marido, disse o seguinte: "Eu fui morar com ela e as pessoas iam atrás dela e aí eu começava a derreter a cera e fazer as coisas para ela. Eu comecei a fazer para ela e aí eu fui atuando na área e aí o pessoal começou a vir e continua vindo" (2019).

Disse-nos Lúcia que atua como benzedeira por conta do amor que sente para com as crianças e que sua especialidade é benzê-las. "Quinem dizem: que venham a nós as criancinhas do reino de Deus. Então eu faço tudo por amor às criancinhas" (2019). Contou ainda que além fazer os benzimentos, também fornece dicas para as mães das crianças.

\begin{abstract}
Que tem mães de primeira viagem que não sabem quase nada sobre ter um filho. Então você geralmente vai dando as orientações. Que daí as mães não sabem, né? Se a mãe está nervosa e ela vai amamentar ela vai passar no leite. O leite já é nervoso e aí ele vai passar as energias negativas para a criança. E aí a gente ensina também que o bebe sempre quer estar na presença da mãe. Então a gente ensina assim: se a mãe usa um perfume, uma coisa assim, ela pode passar nela e no bebe e aí o bebe pensa que ele tá em contato com a mãe. Porque naquele momento ele sente o cheiro, assim, ou uma roupa que a mãe usa ela pode colocar perto do berço do bebe. Ela vai dar mais calma para o bebe, porque o bebe pensa que a mãe está ali. O bebe quer ficar o tempo todo agarrado na mãe, né? Com o cheiro da mãe, né? (Lucia Kruk, 2019).
\end{abstract}

Durante essa entrevista pudemos perceber o quanto as práticas das benzeções estão ligadas ao cotidiano, tanto das pessoas como dos animais; tanto de filhotes quanto adultos. Minha avó e meu avô paternos planejaram um atendimento com uma dessas benzedeiras de origem polonesa porque alguém lhes dissera ser ela a pessoa mais preparada para cortar o ar. Nossa conhecida Leoni ${ }^{5}$ havia diagnosticado que o idoso retinha muito ar

\footnotetext{
${ }^{5}$ Benzedeira em Irati no bairro Santo Antônio.
} 
no corpo. A quantidade era tão alta, disse ela, que somente uma especialista em queima de ar poderia ajudá-lo. Eu fui os acompanhando. A especialista indicada chamava-se Maria Frontik, vizinha próxima de Lúcia. Maria Frontik nasceu em 1931, e segundo ela, é benzedeira desde criança.

Ao chegarmos à casa de Maria fomos recebidos por ela e por seus vários gatos. Ela nos contou que morava sozinha, desde que seu marido faleceu, há vinte anos, mas seus filhos, que residem em Rio Azul iam visitá-la quase todos os dias. Segundo o que disse, quando “[...]chegava da escola e a mãe dizia, veja lá aquela criança... não está boa. E a gente ia lá, fazia uma oraçãozinha e ela melhorava" (2019). Disse também que aprendeu a benzer com uma tia que também era benzedeira e que quando era pequena, conversava com os vizinhos em polonês, mas que hoje em dia não consegue mais se lembrar das palavras. "Era, mas eu agora não lembro mais polonês. [...] E aí esquece” (2019).

Explicou que, entre as doenças que as pessoas costumam procurar por sua ajuda, estão também situações que ela não pode ajudar. Que não são assuntos que benzedeira possa ajudar:

Muitos... qualquer coisa eles pensam que a gente ajuda. Tipo uma moça lá briga com o rapaz e aí ela vem aqui para ver se ele volta com ela. Digo essas coisas a gente não... eu não lido com essas coisas de baralho e essas coisas. Não, não é comigo. Eu só sei tirar susto, benzo de cobreiro, queimo o ar e faço costura para machucadura. Essas coisas de benzedeira, né? (Maria Frontik, 2019).

A menção à doença chamada popularmente de cobreiro na língua portuguesa levantou a questão, durante a entrevista, de como seria nomeada tal enfermidade em polonês. Maria é de origem polonesa, mas não utiliza mais a língua, o que seria uma boa oportunidade para entrarmos no espaço da cultura popular eslava.

Cobreiro é o nome português para uma série de afecções da pele que estariam associadas ao contato com as serpentes, as aranhas e a outros animais peçonhentos. $\mathrm{O}$ nome na língua portuguesa relaciona-se a um animal, (cobra) assim como o sapinho (sapo) e a chamada doença de mico (macaco). A questão que emergiu, então, era saber se na língua polonesa, na cultura eslava, este tipo de doença que estas benzedeiras lidavam tinham também nomes de animais ou se tal forma de nomeação seria típica das culturas de matriz portuguesa/indígena/africana.

Aproveitei para entrevistar Maria que em seguida pediu para que eu chamasse meus avós para atendê-los. Assim que meus avós entraram perguntou o que estava acontecendo e minha avó contou. 
Ele está com muito ar no corpo. Uma benzedeira perto de casa benzeu ele, mas disse que ele precisava procurar uma que pudesse queimar o ar. Durante a noite ele fica se repuxando, repuxando o corpo. E agora está aparecendo umas bolinhas na cabeça dele. Até fiz ele raspar o cabelo bem curto para ver se sarava, mas não sarou. ${ }^{6}$

A benzedeira logo em seguida respondeu: "é ar, é muito ar que tem nele. Por isso ele fica se repuxando quando dorme. Mas nós vamos cortar, vamos queimar todo esse ar aí e ele vai ficar bom" (Maria Frontik, 2019).

$\mathrm{O}$ rito de queima de ar praticado por Maria Frontik consistiu no seguinte. Primeiro ela pediu para que meu avô deitasse de lado num sofá com o rosto virado na direção da parede. Em seguida, cobriu a cabeça dele com um pano. Sobre a cabeça coberta, colocou um pouco de pólvora em cima do local onde fica a orelha. Em seguida, pegou um pequeno ramo de palha e uma caixa de fósforo. Depois de fazer uma reza com a voz muito baixa, acendeu o fosforo e queimou a ponta da palha que estava em suas mãos. Com o material em chamas, aproximou o fogo da pólvora e uma lavareda de cerca de vinte centímetros de altura surgiu junto com um pequeno estrondo. Até mesmo a benzedeira se assustou com a altura do fogo e comentou "nossa vida, que ar forte. Pegou ar da réstia (2019).

Após o benzimento Maria explicou que nem todas as benzedeiras queimam o ar e que ela mesma já estava com dificuldades de continuar fazendo devido às barreiras que estava encontrando para comprar a pólvora. Explicou que compra “[...] essa pólvora lá de Irati. Minha neta me traz. Por aqui eles não vendem e não tem. Lá também não estão querendo vender, porque muitos jovens compram para fazer bomba caseira" (Maria Frontik , 2019). Temos nessa fala também um exemplo de benzimento que logo vai precisar ser modificado. Ela nos disse que também benze animais, mas como informou que não sabia mais a o polonês fomos procurar outras pessoas que benzem e usam o idioma.

A benzedeira Telina Qulis e a benzedeira Palmira Lewandowski, que iremos apresentar logo em seguida, moram em localidades bem afastadas da cidade. Recorremos à ajuda de Reguina, que havia conhecido durante o intercâmbio na Polônia. E que conhece algumas pessoas com ascendência polonesa na cidade de Mallet e, entre elas, pessoas que se enquadravam no perfil que estávamos buscando. O primeiro contato foi o benzedor Zugmundo Rosinek, mas ao entrarmos em contato, seus familiares nos informaram que

\footnotetext{
${ }^{6}$ Com base na fala de Maria da Luz Gonçalves, feita para a benzedeira Maria Frontik em 2019.

${ }^{7}$ Raio de sol.
} 
ele não estava bem de saúde e que mal conseguia se comunicar. Sua filha, então, nos passou o nome de Palmira Lewandowski e nos disse que esta morava na localidade do Braço Salto do Potinga, próximo à divisa entre o município de Rio Azul e de Mallet. Informou também que Palmira era uma amiga da família e que também falava polonês.

Encontrar a casa indicada foi bem difícil, primeiro porque não conhecíamos a região interiorana de Rio Azul e de Mallet e também porque pelas informações que tínhamos, ela ficava numa localidade afastada da cidade, pelo menos uns vinte quilômetros. Por sorte, encontramos algumas pessoas que a conheciam e que nos disseram que estávamos no caminho certo.

Quando encontramos o lugar, fomos atendidos pela família da benzedeira que estava reunida na varanda de sua casa. Estavam presentes seu marido, sua filha, sua sogra e uma criança pequena que era seu neto; além disso, de alguns gatos e dois cachorros faziam parte do grupo.

Palmira nos contou que já trabalhava como benzedeira há cerca de trinta anos, isso é desde 1990 e que havia herdado o conhecimento de sua mãe. "Aprendi com a minha matka ${ }^{8}$ minha mãe era benzedeira e ela pegou do pai dela e aí ela passou pra mim" (2019). Disse que tanto sua mãe, quanto seu avô eram ascendentes de poloneses e que as pessoas da sua região costumam procura-la em busca de benzimentos e também de simpatias. "Sim tem bastante. Tem bastante gente que busca por aqui. Para bronquite, mordida de aranha, mordida de cobra, costurar machucadura eu faço, tirar susto e eu faço assim para animais também, né?” (2019).

Em relação à cura de animais, os casos mais frequentes são: “[...] berruga nas tetas das vacas, mordida de aranha, de cobra em cavalos e na vaca também, né? Bicheira também faço, né?” (Palmira Lewandowski, 2019). De acordo com seu relato, parece ser um procedimento normal. "Ah! Para bicheira, faço muito. Muita gente vem procurar e aí a gente reza. Faz os pedidos e funciona" (2019).

Outro detalhe importante na fala de Palmira... Ela se nega a benzer cachorro, gato e cabrito. Disse que "[...] para o gato, não se faz benzimento; para cachorro não se faz benzimento, porque não pode; e para cabrito, também, não faz benzimento" (2019). Disse que não sabia explicar o motivo da proibição, mas que sua mãe havia the ensinado daquela forma. Enfatizou que não chegava a ser uma proibição, mas uma informação de que a benzeção destes animais não surtia efeito algum. Este seria um dado a ser investigado para saber se se trata de uma particularidade do universo cultural das benzedeiras de

\footnotetext{
${ }^{8}$ Matka em polonês é Mãe.
} 
tradição eslava. Em todo caso, nota-se, aí, uma configuração específica das fronteiras entre a câmara dos animais humanos e a dos não humanos. Cães, gatos, cabritos e animais selvagens estariam numa posição inferior à das criaturas não humanas que podem ser benzidas.

Palmira informou, também, que quando as pessoas precisam de cura para um animal que não se pode ou que seja de difícil transporte até ela, recorre a um procedimento especial: faz o benzimento através do nome do animal que deve ser informado pelo dono.

Aqui benzimento de animais eu faço também pelo nome. Assim, por exemplo: mordida de cobra para os animais, para o cavalo ou para a vaca que não consegue vir até aqui. Aí, eles não procuram veterinário. Eles vêm primeiro aqui. Daí, se adianta não precisa, né? Eu faço no rio com faca. Aí tem que pegar água e aí a água eu dou para levar para casa. Aí, eles têm que passar três vezes. Não... nove vezes passar a água (no ferimento) e também têm que cuidar da comida, né? O que você vai dar de comida (Palmira Lewandowski, 2019).

A benzedeira pode ser considerada como uma espécie de pronto atendimento dos animais domésticos, no caso, de picadas de cobras. Mas o dado de que o animal pode ser curado por meio do nome demonstra a proximidade das relações que estes agricultores estabelecem com os animais domésticos. Thomas (2010, p. 134) escreveu a respeito deste assunto. Na Inglaterra do início da idade moderna,

Ovelhas e porcos não costumavam receber nomes individualizados,
mas as vacas sempre os tinham; não nomes humanos, pois a distância
havia de ser preservada, mas nomes de flores, como cravo ou lírio, ou
epítetos descritivos que com frequência, denunciavam afeto por parte
do proprietário. Em Essex, na época Tudor havia vacas com o nome
Bondosa, Nariz castanho, Cabelos brancos, Botão e Graciosa. [...] Os
touros tinham nomes menos lisonjeiros e emotivos, embora alguns
fossem chamados de Bem-amado e Soberbo. Os bois de tiro, sob a
mesma canga, traziam pares estereotipados de nomes destinados a soar
distintamente, quando o lavrador os chamassem: Crespo e Castanho,
Águia e Falcão [...].

Atualmente, na região em que acontecem estas benzeções, como em outras regiões do Brasil em que o contato dos humanos com vacas, bois e cavalos é cotidiana, estes continuam a receber nomes específicos. Mas é preciso considerar que a distância entre o mundo dos animais domésticos e dos animais humanos foi aumentando durante o período moderno, quando surgiu uma nova sensibilidade, uma nova estética em que os animais de 
criação foram sendo alijados dos espaços domésticos.

Durante a entrevista com Palmira ouvimos várias palavras em polonês, tais como dziadek que tem como tradução avô. Matka que é mãe em polonês. E em certo momento quando ela referiu-se uma doença que afetava os cavalos, ela utilizou-se da palavra travagem e demonstrou que não conhecia essa doença por um nome em português.

[...] travagem é em polaco. É tipo um sapinho que dá em cavalo. Ele cresce no céu da boca do cavalo, daí aparelha com os dentes e o aí o cavalo não come. E aí para terminar com isso, você esquenta um ferro quente e queima. Mas daí eu faço o benzimento e ele desaparece, sem precisar judiar do bicho. Aí não precisa queimar (Palmira Lewandowski, 2019).

Como a benzedeira referiu-se a esta doença com nome na língua polonesa, perguntamos se conhecia o nome de outras. Respondeu que não sabia todas, mas que falaria de algumas: "[...] dor de dente que muita gente busca, essa é Ból zęba; dor de cabeça que também procuram é Ból Głowy. Aí, tem também essa doença que chamam mingua de macaco que chamam. Aí em polaco é Suszone”. Outras doenças citadas pela benzedeira foi "sapinho = Betki" (Palmira Lewandowski, 2019). e "bicheira em polaco é Robak... Robactwo" (2019).

Com a ajuda de Sônia Niewiadomski buscamos compreender quais eram as traduções destes termos e também se tinham ligação com animais como no nome português. Para isso utilizamos de dicionários online e também de alguns sites, mas o acesso a essas informações não são tão fáceis, por que não são muito pesquisados e também porque na Polônia muitos sites com artigos científicos só são acessíveis por meio de pagamento o que dificulta o acesso a informações.

A explicação para as duas primeiras palavras é mais simples: Ból zęba, que neste caso está no genitivo tem como tradução dor de dente, pois ząb $=$ dente e Ból $=$ dor. E a palavra Ból Głowy tem como tradução dor de cabeça, sendo Ból Głowy = dor de cabeça.

Quando perguntamos se Palmira conhecia o nome para bicheira em polonês, ela ficou na dúvida e precisou pensar um pouco antes de responder. Com a ajuda do marido que tem ascendência polonesa e usuário da língua, respondeu que seria Robak (SŁOWNIK języka polskiego PWN, 2019) Robactwo (SFEROPEDIA, 2019). Ficou na dúvida entre as duas palavras. Robak em polonês significa verme, larva e parasita. Enquanto isso, Robactwo é denominação para designar conjunto de vermes, larvas ou parasitas.

Podemos compreender, portanto, que as duas palavras descrevem o que seria a doença bicheira, uma ferida causada por vários vermes ou larvas que se alimentam da 
carne do animal ainda vivo. Ouvindo a entrevista gravada, Sônia pode notar que Palmira falava Robactwo, com “s” e não com “c”. Pronunciava Robastwo, que segundo Sônia pode ser uma variação dialetal na Polônia. A bicheira também pode ser designada como miíase, entre os veterinários, o que seria traduzido, em polonês, como Muszyca ou ainda larwa wędrująca (WIKIPEDIA, 2017).

Palmira aplicou o termo Betka (MALINOWSKI, 2008) para a doença chamada sapinho. Essa palavra assim como Robak também possui algumas variações. Pode ser Betka, Betki quando é no plural, mas nenhuma delas significa sapo ou outro animal. O termo aplica-se a uma espécie de cogumelo que, embora comestível, é classificado como produto de má qualidade (WIKIPEDIA, [21-?]). Afirma-se que, na Polônia, as pessoas ricas comiam os cogumelos do tipo $G r z y b$, de qualidade melhor e mais bonitos, enquanto que os mais pobres eram obrigados a comer os fungos mais feios, de qualidade inferior e conhecidos como Betka.

Pelo que conseguimos encontrar a respeito dessa palavra, é pouco usada atualmente na Polônia, mas levando em conta que essas pessoas com ascendência polonesa que se instalaram no Brasil no final do XIX e início do XX, é normal que o termo seja utilizado aqui. É interessante notar que o nome popular da candidíase em polonês não tem relação com um animal e sim com um vegetal. Mas há outra doença que se relaciona a um animal, a mingua.

A mingua de macaco, segundo Palmira chama-se Suchoty. (DOROSZEWSKI, 1958-1969). Em polonês essa palavra é utilizada com o significado de tuberculose (POLKI.PL, 2019) ou como moléstia da garganta (SŁOWNIK języka polskiego SJP, [21?]). Segundo Sônia os ascendentes de poloneses da região do Paraná costumam utilizar a palavra Suchy para designar pessoas magras. Suchy ou sucha, que estão no gênero masculino e feminino são sinônimos para a palavra seco em português. Por exemplo, suchy kaszel significa tosse seca ou sucha kiełbasa que se traduz como linguiça não gordurosa.

Algumas doenças em polonês possuem significados parecidos com as em português, como Robak e da bicheira. Outras é preciso compreender a forma como a língua polonesa era na época da vinda dos imigrantes para o Brasil como o caso da palavra Betka. O mais interessante é constatar que algumas doenças tratadas através de benzimento, na língua portuguesa são associadas a animais como é o caso do sapo e do macaco. As mesmas moléstias, tratadas da mesma forma por meio de rezas, por ascendentes de poloneses não têm a mesma associação no nome com animais não humanos. A candidíase é associada a um cogumelo, enquanto a mingua, à magreza. 


\section{CONCLUSÃO}

No decorrer desta pesquisa buscamos mostrar um pouco do rico universo da bezenção que estas pessoas que tivemos acesso fazem parte. Com o auxilio da metodologia da História Oral, pudemos coletar e analisar uma parte da história de vida dessas mulheres, que abrem a porta de suas casas para atender e ajudar todas as pessoas que acreditam em seus dons. E como pudemos perceber muitas vezes elas passam a atender até mesmo animais de estimação da mesma maneira e com a mesma atenção que atendem uma pessoa.

Durante a entrevista com a benzedeira Sonia, ela disse o seguinte: "nós fazemos muita coisa, nós sabemos muita coisa e quanto mais você for estudando, mais você vai aprendendo" (2019). Com essa fala podemos salientar que essa pesquisa revela apenas alguns detalhes desse rico universo e não abrange ele em sua totalidade. Mas também com essa pesquisa esperamos ter demonstrado a importância destas benzedeiras que como suas práticas culturais ajudam seus pacientes, sejam eles humanos ou não. Trata-se de um universo rico e que merece ser investigado. 


\section{FONTES ORAIS:}

KRUK, Lúcia (Lucia Kruk) [54 anos]. [mar. 2019]. Entrevistador: William Franco Gonçalves. Rio Azul, PR. 03 mar. 2019.

FRONTIK, Maria (Maria Frontik) [88 anos]. [mar. 2019]. Entrevistador: William Franco Gonçalves. Rio Azul, PR. 05 mar. 2019.

LEWANDOWSKI, Palmira (Palmira Lewandowski) [53 anos] [mar. 2019]. Entrevistador: William Franco Gonçalves. Mallet, PR. 04 mar. 2019.

SIDOSKI, Sonia Maria (Sonia Sidoski) [50 anos] [mar. 2019]. Entrevistador: William Franco Gonçalves. Irati, PR. Irati, PR. 16 mar. 2019.

QULIS, Telina (Telina Qulis) [81 anos] [mar. 2019]. Entrevistador: William Franco Gonçalves. Rio Azul, PR. 04 mar. 2019.

\section{REFERÊNCIAS:}

CZERNIDEAK KOŁPAKOWATY. In: WIKIPEDIA: wolna encyklopedia. [21-?]. Disponível em: < https://pl.wikipedia.org/wiki/Czernid\%C5\%82ak_ko\%C5\%82 pakowaty>. Acesso em 14 jun. 2019.

FERREIRA, Marieta de Moraes; AMADO, Janaína. Usos e abusos da história oral. 8. ed. Rio de Janeiro: FGV, 2006.

GONÇALVES, William Franco. "Deus deixou o médico e deixou o benzedor": um estudo sobre as benzedeiras e benzedores de Irati/PR (1957-2014). 2015. Trabalho de conclusão de curso (Graduação em História) - Universidade Estadual do Centro Oeste, Irati, 2014.

GONÇALVES, William Franco. "Adoro, faço com carinho, com amor": reza e Benzeção em Irati-PR. Interações, Campo Grande, MS, v.19, n. 2, p. 257-264, abr./jun. 2018.

GRUZLICA. Polki.Pl. 2019. Disponível em: <https://polki.pl/zdrowie/encyklopediachorob,gruzlica-pluc,8,choroba.html>. Acesso em 14 jun. 2019.

MACIEL, Márcia Regina Antunes; GUARIM NETO, Germano. Um olhar sobre as benzedeiras de Juruena (Mato Grosso, Brasil) e as plantas usadas para benzer e curar. Boletim do Museu Paranaense Emilio Goeldi. Ciências Humanas, Belém, v. 1, n. 3, p. 61-77, 2006. 
MALINOWSKI, Maciej. To dla mnie bedłka (bedka, betka). Obcy język polski Blog o poprawnej polszczyźnie od roku 2002. Łódź, 6 ago. 2008. Disponível em: $<$ https://obcyjezykpolski.pl/to-dla-mnie-bedlka-bedka-betka/>. Acesso em 14 jun. 2019.

MUSZYCA. In: WIKIPEDIA: wolna encyklopedia. 2017. Disponível em: $<$ https://pl.m.wikipedia.org/wiki/Muszyca $>$. Acesso em 14 jun. 2019>

NIEWIADOMSKI, Sônia Eliane; COSTA, Luciane Trennephol. Lenição e epêntese em grupos consonantais tautossilábicos na língua polonesa falada em Cruz Machado, Paraná. Palimpsesto, n. 28, p. 415-439, 2018.

ROBACTWO. In: SFEROPEDIA. [21-?]. Disponível em: <https://sfery.fandom.com/ wiki/Robactwo>. Acesso em 14 jun. 2019.

ROBAK. In: SŁOWNIK języka polskiego PWN. [21-?]. Disponível em: $<$ https://sjp.pwn.pl/sjp/robak;2515423.html>. Acesso em 14 jun. 2019.

SUCHOTY. In: DOROSZEWSKI, Witold (Red.). Słownik języka polskiego. Warszawa: PWN, 1955-1969. Disponível em: <https://sjp.pwn.pl/doroszewski/suchoty;5502218. html>. Acesso em 14 jun.2019.

SUCHOTY. In: SŁOWNIK języka polskiego SJP. [21-?]. Disponível em: <https://sjp.pl/ suchoty> Acesso em 14 jun. 2019.

TELEGINSKI, Neli Maria. Bodegas e bodegueiros de Irati-PR na primeira metade do século XX. 2012. 250 f. Dissertação (Mestrado em História) - Setor de Ciências Humanas, Letras e Artes, Universidade Federal do Paraná, Curitiba, 2012.

THOMAS, Keith. O homem e o mundo natural: mudanças de atitudes em relação às plantas e aos animais (1500-1800). São Paulo: Companhia das letras, 2010.

VAZ, Vania. As benzedeiras da cidade de Irati: suas experiências com o mundo, e o mundo da benzeção. 2006. 148 f. Dissertação (Mestrado em História) - Pontifícia Universidade Católica de São Paulo, São Paulo, 2006. 